\title{
The Librarian as Teacher in the College Library'
}

\author{
Miss Brown is librarian, Skidmore Col- \\ lege.
}

I

THE instruction of students in the use of the library the librarian becomes himself a teacher and realizes his direct contribution to the educational program of the college.

There are two inherent difficulties in giving such instruction to freshmen. The greatest difficulty is that the subject is not in itself fascinating, like the plays of Tennessee Williams or the burial customs of the Samoans. The ability to use the library is a tool which is appreciated only when the need for it has been felt. The second difficulty lies in the widely varying library backgrounds found among new college students. Great as have been the strides made in library facilities at the elementary and high school levels, many students still enter college with perhaps only the ability to make partial use of the library card catalog. For these two reasons, no instruction can be so successful as the individual guidance given at the reference desk to the student who comes voluntarily seeking help. The library in the college with a small enrolment, which can handle the instruction of entering freshmen on an individual basis, is indeed fortunate. However, many college libraries prefer to give freshman instruction on a group basis, partly to prevent an excessive burden on the reference staff, and partly because they fear some new

1 Paper presented at the Conference of Eastern College librarians, Columbia University, Nov. 27, 1948. students may be in ignorance of their own lack of library knowledge.

This group instruction of new students may be given in one of several ways: in connection with an academic course, as part of an orientation program or course, or as a separately scheduled library project. Instruction in connection with an academic course calls for a course which is required of all new students and for which library materials furnish the tools. An examination of a representative group of college catalogs reveals that many institutions require of first year students a course designed to increase their facility in reading, understanding, writing and speaking the English language. These courses may be listed quite simply as composition, or English, or in the more modern parlance, as communication. The latest Barnard College $\mathrm{An}$ nouncement rather happily sums up the evident general purpose of these courses:

"The College believes that every student should be able to speak and write good English, and that her mind should be trained to think straight, weigh facts, and seek the truth. Such abilities may be developed in many courses and activities, but specifically the Faculty requires English $\mathrm{A}$ as helpful toward this end."

Courses of this type, where they exist, provide an ideal opportunity for libraryfaculty cooperation in teaching the use of the library. The classroom work, with its emphasis upon themes, shows the student his need for the instruction and provides 
him with opportunity to put into practice what he learns. The instructor in the course usually plans to bring his class to the library for an hour or two of instruction during regular class periods. We have found that the presence of the classroom instructor, who may enter into discussion with the librarian and who may stay for a few minutes after the formal instruction period to help answer students' questions, aids in establishing rapport. Some of the instructors give follow-up problems which will help fix in the students' minds the important points covered by the library lecture.

In some institutions students may secure exemption from these courses in composition, or English, or communication, by passing an exemption examination. The library then has a choice of giving library instruction as a separate library project to all the students exempted, or of conducting a library test to determine whether some of the entering students may be excused. It is evident that in case the library chooses to administer such a test, it should be given to the entire group of first year students, since proficiency in understanding and writing English does not necessarily indicate proficiency in the use of the library. Some interesting studies of the degree of correlation between the two skills might certainly be made in various colleges, however. Libraries reporting success in the use of these tests have usually made or adapted them to their own particular situation.

The content of freshman instruction in the use of the library and consequently, the material covered in tests of library knowledge, includes the same minimum or core in almost every situation. This minimum is the use of the card catalog as the index to the book material in the library and the key to its location in the stacks, and the use of periodical indexes. To this mini- mum, we recommend the addition of the use of the Essay and General Literature Index as the guide to material in parts of books. Each library will add to this basic instruction according to the needs most frequently shown by freshman students in the particular college. The teachers of first-year courses and the library service-desk personnel, who meet freshman problems repeatedly, should be asked for suggestions of material to be included in the library instruction. As a starting point for freshman themes the general encyclopedias and the standard English and American biographical dictionaries are frequently included. The value of including any special subject tool is doubtful unless it can be linked immediately to the student's daily experience or to his work in an academic course.

The timing of the instruction is important. Early in the academic year we have to compete with the pressure of many activities and new impressions, and often with homesickness. Yet instruction must be given early if the library staff is not to be unduly burdened with individual guidance. After several weeks, on the other hand, the need for instruction becomes more apparent to the student.

At Skidmore we have arrived at what we think is a happy compromise. Two hours of instruction are given to each section of the freshman English classes. This compromise is the result of a trial last year when some of the entering students were given both hours of instruction in the first week of the semester, and others were given only one hour's teaching in the first week, including the use of the card catalogue, the Essay Index, the standard biographical dictionaries and the general encyclopedias. The students in the second group were given their hour's instruction in the periodical indexes in the fourth 
week, just before they started work on their term papers. We found that the students in the first group, faced with writing papers, were returning in droves to our service desk to be shown over again how to use the periodical indexes. Now the first hour's instruction, which is given to all freshmen early in the second week of the fall semester, includes the use of the card catalog, the Essay and General Literature Index, the general encyclopedias and the standard biographical dictionaries. The second hour's instruction, in the use of periodical indexes, is given to each section of the class just as it begins work on the term paper. This practice has met with noticeably greater success. Since the work of the classes has been planned so that the sections begin work on the paper in successive weeks, the library instruction periods have been spread out and the weekly teaching load on the library staff lessened.

Some college library staffs give formal credit courses to students in the use of the library, the courses continuing in most cases throughout one semester or term. In the past these courses have usually consisted of lectures covering the use of library tools, beginning with the general group and then continuing through the major subject fields.

Now we are coming to recognize that such courses are basically unsatisfactory in that they force students to study subject bibliography for which they have no immediate need, and in the use of which they will have no early practice. Various attempts to offset the difficulties inherent in such instruction may be traced through current college catalogs. One modification is the placing of more emphasis on the history of books and libraries, thus giving the course substance and dignity in its own right. Other courses stress the sources of information on present day problems; some give more attention to the method of working and permit the student to concentrate on an independent project, frequently a bibliography to support a paper in another course.

I think you may be interested, in this connection, in a recent decision we have made at Skidmore. We have been offering a one-semester, one-credit course known as Bibliography 301 , open to juniors and seniors with the permission of the instructor. This permission clause has given us the opportunity to ask each student, before enroling her in the course, why she wanted to take it. Several impressive reasons have been offered, but only one student had the innate honesty, or courage, to admit to me that it was the only one point credit course that fitted her schedule. Of the 18 students who attended classes during two years at Skidmore, it appears that only seven English majors and six chemistry majors had sufficient motive for electing the course. The other students, who obviously had needed one credit to round out their programs, were correlating the work of the course with work in art, physical science or philosophy courses.

Each student showed interest in, and was ready to profit by, several classes during the semester: the hours during which we discussed the theoretical aspects of bibliography, the card catalog, general aids and government documents, and the classes which covered particular fields in which the student was studying. However, each was forced to spend several hours considering groups of tools in which she had no interest. This seems to me a great waste of time for both students and instructor.

With the concurrence of the Curriculum Committee, which is yet to be consulted, we are planning to drop this course and offer instead to extend our teaching of class groups in the bibliography of their subject. Members of the chemistry department, 
upon being approached for their reactions to the proposal, proved so responsive that they are planning to include the literature of chemistry in the department seminar, the bibliography to be taught jointly by a member of the department and the librarian.

Members of the English department, also approached as being the other group chiefly concerned in the change, have replied favorably. This year we met informally with a group of students from the English seminar for a discussion of the tools of special importance to them in the preparation of their papers, but the time allowed was too short and attendance voluntary. The staff had to follow up with hours of individual instruction. Next year, we shall meet the students during regular class periods. We are already following this plan successfully with the history seminar.

We are going on the theory that it is better to spend our time in teaching the use of subject tools to class groups who will have immediate use for them, than in giving more extensive instruction to the few students who elect Bibliography 301 and have no practical use for about half the course.

In making our plans to drop the course rather than to transform it into another type of course, we have been influenced by the college curriculum and by the size of our staff. Much as we should enjoy giving a two or three credit course combining the historical background of printed sources of knowledge with a survey of the basic general and subject bibliography, we think there is little place for it in our college program which encourages the combination of vocational with liberal arts courses. The college believes that a girl may take a generous amount of work in any of the vocational departments of the college and still be eligible for the Bachelor of Arts degree and conversely, "that the physical education teacher, the nurse, the dietitian, or the commercial artist, is a better professional woman and a better citizen if at least half of her college course is made up of the familiar liberal subjects." Such a philosophy in practice leaves little room in any student's program for nonessentials.

Our second consideration is that our comparatively small staff must spend available instruction time in the way which will most benefit the greatest number of our students.

This teaching of students in class groups involves preliminary discussion with the instructor regarding material to be covered and regarding individual projects of the students in the class. It is essential that the library staff not only understand the plan of the course, but be kept informed of assignments involving special use of library materials. The library should maintain, as a matter of routine, complete files of class outlines, reading lists, and assignment sheets.

Unquestionably it is the informal teaching of individual students by the reference staff which meets with the greatest measure of success, because the instruction is given in answer to a specific personal need that has just been felt.

The peculiar contribution of this individual teaching done by the reference librarian is his part in helping students to clarify their problems and to go logically about solving them. The member of our staff in charge of readers' service said to me the other day, when we were discussing this point, "Whose responsibility is it to help these girls think through their problems?" Perhaps the responsibility lies largely with the classroom instructor, but he certainly shares it with the library reference 
staff. Some students, confused in defining their projects, will seek a conference with their instructor; others will go directly to the library. requesting information as to where to find material on a startlingly broad subject or on a fuzzily defined subject. In dealing with these students, it is essential that the reference librarian acknowledge, accept and enjoy his own role of teacher; it is essential that he refuse to state the problem for the student, but that by patient, tactful and understanding questioning he lead the student to think it through for himself.

The teaching activity of the reference staff will always reflect the educational program of the college/ Institutions which emphasize the type of instruction in which students work out individual problems of interest to them will naturally provide to the library staff the greatest instructional opportunities.

It is important that library staff members continue to regard themselves as teachers in their relations with their student assistants. The full educational possibilities in student assistantships will be realized only when the staff supervisors take pains to assign jobs so far as possible in accordance with the students' interests. They should also interpret to them the place of necessary routine jobs in the work of the library as a whole, and finally insist on a satisfactory standard of performance.

There will always be two limitations to the educational potentialities of student library jobs. The primary purpose in employing student assistants is to get the work of the library done. Since students are for the most part untrained, short-term help, many of them must be assigned to routine work. The second limitation is the degree of receptivity and imagination of the student himself, which will govern the extent to which he will profit by the educa- tional possibilities of his job. A Skidmore student shelving just three hours and twenty minutes a week was assigned to reading shelves in the section where the books in her major field of interest were located. She emerged from the first week's work in a glow because she was finding out about books which she did not know existed. Another student would make dull routine of the same job. Let us not forget that education is a two-way process!

Student assistantships of educational value will fall roughly into four classifications. First are jobs in which the student works in the subject field of his interest or has the opportunity to practice what he has learned in the classroom. In this category are assistantships in divisional or departmental reading rooms, poster making, checking orders for foreign language books, etc. In a second group are positions which open up to the student a new field of knowledge. Examples of this class are the acquisitions department job which gives the student assistant an introduction to the book trade, or work in the mechanical preparation of books which involves an understanding of book construction and may lead a student, on suggestion from his supervisor, to read McMurtrie's The Book or a similar title. Then there are jobs through which students may increase their knowledge of present day problems and of the sources of information on them. Work on exhibits is particularly fruitful in this respect. A student assistant in the Skidmore Library looks up material for the exhibit which is maintained in connection with our weekly Open Forum radio program on vital issues of the day. The exhibit is supposed to present authoritative material, in not-too-lengthy form, which will provide background information for intelligent audience participation. Part of

(Continued on page 150) 
procedure, writers be encouraged to include a symbol indicating the location of the books referred to in any bibliographic citation. In the course of a few years, the nation would have innumerable union catalogs in subject form indicating locations of large segments of research material. Since scholars usually get their information on books wanted from such bibliographical citations, they would at the same time have available information as to the location of the book. A suggested bibliographic citation form, including the symbol device for the holding library, might be set up as follows:

Parker, Nathan H. Missouri Hand-book. St. Louis, P. M. Pinckard, 1865. (MoSW)

These two solutions: one a suggestion for a bibliographic device to perform some of the functions of union catalogs; the other, two proposals for relieving libraries of their most pressing problem in the extension of interlibrary loan service, are recommended. Continued international rivalry will undoubtedly require greater integration and extension of research on a national scale. Libraries have a crucial role in this picture, for no research can be adequate without ready access to materials. It is suggested that librarians present the interlibrary loan problems as one aspect of what is a national problem: the problem of promoting research and improving research facilities. It can be presented as such to the federal government in lobbying for extension of franking privileges. It can also be presented as such to research institutions and workers in securing their cooperation in the use of library symbols as a standard part of bibliographic citations.

\section{The Librarian as Teacher}

(Continued from page 123)

the exhibit consists of four or five questions which are suggested as fundamental to the problem. Although a staff member assumes final responsibility for the exhibit, the student assistant obviously must scan the material available to make a preliminary selection and to suggest pertinent questions.

Finally there is the large class of student jobs which are of educational value chiefly because they help develop good personal qualities, sense of responsibility, habit of carrying work through to completion, ability to organize work, etc. These should, of course, accompany anything else the student learns. There are some types of work which are particularly helpful in this respect-for example, service at a reserve desk where the student may be left in charge at certain periods. The development of these qualities in the student assistant depends upon good personnel practice in the library and the teaching ability of the staff member who supervises the student's work.

The opportunities open to the librarian as a teacher in the library are almost limitless. It remains only that he accept and welcome these opportunities and participate actively in this role. 